\title{
Double Jeopardy and Appeal of Dismissals: A Before-and-After Approach
}

The double jeopardy clause of the fifth amendment provides that no person shall "be subject for the same offense to be twice put in jeopardy of life or limb."1 Although this phrase appears simple, it has generated complex constitutional debate. One particularly troublesome issue has been whether the double jeopardy clause prevents the government from appealing a dismissal of criminal charges when reversal and remand would require further court action which could be considered a second "jeopardy."

In a trilogy of cases in 1975, the Supreme Court adopted a rule designed to provide clear guidance on the issue. ${ }^{2}$ The Court held that the double jeopardy clause bars government appeal of a trial court dismissal if reversal and remand would create a need for "further proceedings of some sort, devoted to the resolution of factual issues going to the elements of the offense charged." 3 Under this "further proceedimgs" test, the government could appeal a pretrial dismissal. As a pretrial dismissal occurs before the jury is sworn or either side presents evidence to the court, jeopardy would not have attached. ${ }^{4}$ The governinent could also appeal a post-verdict dismissal because reversal and remand would not require a new trial, but merely a reinstatement of the verdict. The government could not appeal midtrial dismissals, as reversal and remand would require the defendant to face a second trier of fact.

Three years later, the Court in United States v. Scott ${ }^{5}$ retreated from the further proceedings test. The Court held that where the judge grants a defendant's dismissal motion midway through the trial, the government may appeal unless the dismissal constitutes an acquittal, "a resolution [in the defendant's favor], correct or not, of some or all of the

1. U.S. Const. amend. V.

The double jeopardy clause applies to the states through the fourteenth amendment. Benton v. Maryland, 395 U.S. 784, 793-96 (1969); see Malloy v. Hogan, 378 U.S. 1, 8 (1964).

2. Serfass v. United States, 420 U.S. 377 (1975); United States v. Jenkins, 420 U.S. 358 (1975); United States v. Wilson, 420 U.S. 332 (1975).

3. United States v. Jenkins, 420 U.S. 358, 370 (1975).

4. Jeopardy attaches when the jury is impaneled, Crist v. Bretz, 437 U.S. 28 (1977), or in a nonjury trial, when the court begins to hear evidence, Serfass v. United States, 420 U.S. 377, 388 (1975).

5. 437 U.S. 82 (1978). 
factual elements of the offense charged." 6

This Comment will argue that the Scott test, which inquires whether a dismissal is tantanount to an acquittal, inadequately protects a defendant's double jeopardy interests and unduly complicates double jeopardy analysis, resulting in an unpredictable and costly system of double jeopardy protection. It will propose that the $S$ cott test be replaced with a "before-and-after" jeopardy approach. Under this approach, a trial court could grant dismissals either before trial or after the verdict, but not during trial. All dismissals would be appealable. The before-and-after approach would protect the government's interest in convicting criminals, but would eliminate the danger under Scott that a defendant might lose his double jeopardy protection when a midtrial dismissal comes before a full adjudication of factual issues, either because of mistiming by the defense counsel in inoving to dismiss or because of manipulation by the prosecutor or judge. It would also eliminate the need for a time-consuming and unpredictable appellate search through the record for a ruling meeting Scott's definition of an "acquittal."

Part I of this Comment presents a brief history of the double jeopardy clause and describes the interests the clause protects. Part II analyzes the further proceedings test and the Scott acquittal test in light of the defendant's double jeopardy interests and the government's interest in convicting guilty defendants. Part III then explains how the beforeand-after approach would inore adequately protect a defendant's double jeopardy interests while still preserving the government's interest.

\section{I}

The Double Jeopardy Clause and the INTERESTS IT PROTECTS

The concept of double jeopardy is of ancient origin. ${ }^{7}$ It has been traced to the Greeks and Roinans, ${ }^{8}$ and was establislied in England as early as the thirteenth century. ${ }^{9}$ In drafting the double jeopardy clause

6. Id. at 97 (quoting United States v. Martin Linen Supply Co., 430 U.S. 564, 571 (1977)).

7. For a history of double jeopardy, see M. FrIEDLAND, DoubLE JEOPARDY 5-15 (1969); J. Stgler, Double Jeopardy: The Development of a Legal and Social Philosophy 1-37 (1966).

8. See, e.g., DiGest 48.7.2, cited in Bartkus v. Illinois, 359 U.S. 121, 152 n.3 (1959) (Black, J., dissenting).

9. Bartkus v. Illinois, 359 U.S. 121, 152 (1959) (Black, J., dissenting). The English protection against double jeopardy was primarily a function of the eommon law pleas of autrefois acquit, autrefois convict, and pardon. See United States v. Wilson, 420 U.S. at 340. With some exceptions, these pleas barred the retrial of a person who had previously been acquitted, convicted, or pardoned of the same offense. 
of the fifth amendment, Congress chose language paralleling Blackstone's declaration that it was a "universal maxim of the common law of England, that no man is to be brought into jeopardy of his life, more than once for the same offense." 10

The Supreme Court has articulated the principles underlying the double jeopardy clause as follows:

[T] he state ... should not be allowed to make repeated attempts to convict an individual for an alleged offense, thereby subjecting him to embarrassment, expense and ordeal and compelling him to live in a continuing state of anxiety and insecurity, as well as enhancing the possibility that even though innocent he inay be found guilty. ${ }^{11}$

The double jeopardy clause protects the criminal defendant in three ways: it protects him from repetition of the ordeal of trial; it protects him from an imcreased chance of being convicted although innocent; and it preserves his interest in allowing the jury to exercise its nullification prerogative and acquit against the evidence. ${ }^{12}$

The ordeal of trial can itself be a form of punishment. Criminal prosecutions consume a defendant's time and subject him to painful and embarrassing public scrutimy. He must procure counsel and witnesses, often at great expense. If he cannot afford bail, he may spend months in jail awaiting trial. ${ }^{13}$ A trial also restricts the defendant's right to travel and inay make it impossible for him to hold a job. Throughout the proceedings, he must suffer the anxiety of not knowing whether he will be found criminally hable and whether he will have to serve a prison term. The double jeopardy clause expresses the principle that forcing a defendant to endure the ordeal of trial on the same charge more than once is an undue burden. It is based on the premise that once a defendant has been tried and released, he has the right to plan his future and conduct his life free from the worry of being retried. If, for example, he wishes to marry, have children, move to a new location, or start a new job, he should be free to do so without having to consider the possibility that his case may be reopened.

Also central to double jeopardy doctrime is the belief that giving the government the opportunity to conduct multiple trials increases the risk of convicting an innocent defendant. Forcing a defendant to endure repeated trials may wear down his resistance and exhaust his financial resources. Moreover, the opportumity for multiple trials is an effective discovery tool for the government, as it enables the prosecutor

10. 4 W. Blackstone, Commentaries *335.

11. Green v. United States, 355 U.S. 184, 187-88 (1957).

12. For a slightly different method of categorizing the defendent's interests, see Westen \& Drubel, Toward a General Theory of Double Jeopardy, 1978 SuP. CT. REv. 81, 84, 86. (1968).

13. Note, Multiple Prosecution: Federalism vs. Individual Rights, 20 U. FLA. L. REv. 355, 361 
to preview the defendant's evidence and strategy in a "trial run." It allows the prosecution to correct deficiencies in its own case and prepare a thorough rebuttal for the second trial. ${ }^{14}$ At retrial, prosecution witnesses may be better prepared for cross-examination, ${ }^{15}$ and the prosecution may decide not to call witnesses who divulged exculpating facts at the first trial.

Although the defense may also improve its presentation in a second trial, the defendant does not benefit from multiple trials as much as the government. Current law gives a defendant greater discovery rights than the government, ${ }^{16}$ so the first trial probably teaches the government more than it does the defendant. More importantly, the government controls the decision whether to bring a second prosecution, and can use this power strategically. The opportunity for the prosecution to improve a second presentation in light of lessons learned at the first trial increases the risk of convictimg an innocent defendant and gives him a strong interest $\mathrm{m}$ taking his case to the first jury and avoiding retrial. ${ }^{17}$

Another interest the double jeopardy clause protects is the defendant's interest in jury nullification. ${ }^{18}$ Imphicit in the sixtli amendment right to jury trial is protection agamst government oppression. ${ }^{19}$ The jury can acquit agamst the evidence if it believes the law either generally oppressive or unjust as applied in the particular circumstances. ${ }^{20}$

14. Justice Brennan, dissenting in Scott, explained the problem of allowing the prosecution an opportunity to conduct a second trial as follows:

A retrial affords the Government the opportunity to re-examine the weaknesses of its first presentation in order to strengthen the second. And, as would any litigant, the Government lias been known to take advantage of this opportunity. It is not uncommon to find that prosecution witnesses change their testimony, not always subtly, at second trials.

437 U.S. 82, 105 n.4 (Brennan, J., dissenting); see Arizona v. Washington, 434 U.S. 497,504 n.14 (1978); Carsey v. United States, 393 F.2d 810, 813-14 (D.C. Cir. 1967) (Leventhal, J., concurring).

15. Crist v. Bretz, 437 U.S. 28, 52 (1978) (Powell, J., dissenting).

16. See, e.g., Brady v. Maryland, 373 U.S. 83 (1963); Jencks Act, 18 U.S.C. $\$ 3500$ (1976);

FED. R. CRIM. P. 16.

17. Crist v. Bretz, 437 U.S. 28, 52 (1978) (Powell, J., dissenting); Carsey v. United States, 392

F.2d 810, 813-14 (D.C. Cir. 1967) (Leventhal, J., concurring).

18. See, e.g., Westen \& Drubel, supra note 12, at 146.

19. See, e.g., Duncan v. Louisiana, 391 U.S. 145, $155-56$ (1968); Patton v. United States, 281

U.S. 276, 296-97 (1930).

20. See R. TRaynor, The RIdDle of Harmless Error 32-33 (1970) (footnotes omitted):

Such vetoes of the law by the jury appear quite scrutable once we understand that the jury is passing judgment, not on the evidence as to defendant's conduct, but on the law that prohibits the conduct. Whatever a jury's lack of legal tools for the job, it is still umiquely situated by virtue of its very representation of the conscience of the community, thus to keep the commumity and its laws in reasonable harmony. It is a sinall leeway in the total legal systen, but a sigmificant one, that now and again a jury can return a verdict of not guilty without fear of contradiction. This leeway could easily be closed by allowing appeals fron judgments of acquittal and by imterpreting the doctrine of double jeopardy to sanction retrials after acquittal.

Our acceptance of the principle of jury veto las thus far precluded such closing of 
The jury nullification concept helps explain why the government nay not, following an acquittal, appeal the erroneous exclusion of evidence or erroneous instructions-it is impossible to determine whether the jury was exercising its nullification power and would have reached the same conclusion regardless of the errors. ${ }^{21}$

The defendant's double jeopardy interest inust be weighed against the government's legitimate interest. In order to enforce its laws, the government must be allowed to prosecute and seek conviction of those who commit crimes. This interest is unduly undermined when a guilty defendant is released on double jeopardy grounds because of a defect in his prosecution that does not compromise his double jeopardy interests. Therefore, this Comment will examine not only how well the further proceedings test, the $S$ cott acquittal test, and the proposed beforeand-after approach protcct the defendant's interests, but also how well they protect the government's interest in convicting guilty defendants.

II

\section{The Further Proceedings and $S$ cott Tests}

Until recently, government appeal in criminal cases was limitcd by statute. In 1892, the Supreine Court held that the government could not appeal a criminal case without express statutory authority. ${ }^{22}$ Fifteen years later Congress passed the first Criminal Appeals Act, ${ }^{23}$ which conferred jurisdiction on the Supreme Court to consider criminal appeals by the government in limited circumstances. The Court's construction of the Act resulted in extremely complex and technical rules governing the government's appeal rights. After struggling with the uncertain and confusing Act for inore than fifty years, the Supreine Court concluded in 1970 that it was a failure-"a most unruly child that has not improved with age."24

The following year Congress replaced the statute with a new

\footnotetext{
the leeway despite the obvious contradiction in swearing a jury to apply the law and then tolerating its deliberate refusal to do so. The contradiction is the more apparent because the law has not yet gone so far as to sanction an instruction that the jury can disregard the law or to preclude the clrallenge of a juror who will not swear to apply the law. The very inconsistency bespeaks a systein flexible enough to leave a way open for an occasional jury veto to protect an individual against oppressive laws, harsh penalties, or arbitrary or diseriminatory law enforcement.

Federal judges, by contrast, probably do not have the authority to acquit against the evidence. Westen \& Drubel, supra note 12, at 133. See also United States v. Maybury, 274 F.2d 899, 902-03 (2d Cir. 1966).

21. Westen \& Drubel, supra note 12, at 129-30, 146.

22. United States v. Sanges, 144 U.S. 310 (1892).

23. Ch. 2564, 34 Stat. 1246 (1907) (repealed 1971).

24. Umited States v. Sisson, 399 U.S. 267, 307 (1970).
} 
Criminal Appeals Act, ${ }^{25}$ intended to enlarge the government's appeal rights. The new statute permits government appeal from a district court dismissal of one or more counts of an indictinent or information, "except that no appeal shall lie where the double jeopardy clause of the United States Constitution prohibits further prosecution."26 While the language of the new Act is not dispositive, the Suprenie Court has held that the Act's legislative history makes it clear that Congress intended to reniove all statutory barriers to the government's right to appeal and expand the right to the full extent allowed by the fifth amendment. ${ }^{27}$ Thus, the Court has had to decide what limits the double jeopardy clause of the fifth amendment places on government appeals. ${ }^{28}$

\section{A. The Further Proceedings Test}

In a trilogy of cases in $1975 \longrightarrow$ Serfass $v$. United States, ${ }^{29}$ United States v. Jenkins, ${ }^{30}$ and United States v. Wilson ${ }^{31}$ - the Supreme Court adopted the rule that the double jeopardy clause bars government appeal of a trial court dismissal if, on reversal and remand, there would arise a need for "further proceedings of some sort, devoted to the resolution of factual issues going to the elenrents of the offense charged."32 The rationale behind the further proceedings test is that the double jeopardy clause protects the defendant froin the burden and anxiety of having factual issues retried. Thus, where the jury returns a verdict of guilty but the judge then dismisses the indictment on a ruling of law, the government may appeal because reversal would require only a reinstatement of the guilty verdict, not further proceedings on the question of guilt or innocence. ${ }^{33}$ But where the judge dismisses the indictunent after jeopardy attaches but before a verdict is returned, there can be no

25. Omnibus Crime Control Act of 1970, tit. III, Pub. L. No. 91-644, § 14(a), 84 Stat. 1890 (codified at 18 U.S.C. $\$ 3731$ (1976)).

26. Id. The relevant portions of the statute provide as follows:

In a criminal case an appeal by the United States shall lie to a court of appeals from a decision, judgment, or order of a district court dismissing an indictment or information as to one or more counts, except that no appeal shall lie where the double jeopardy clause of the United States Constitution prohibits further prosecution.

....

The provisions of this section shall be liberally construed to effectuatc its purposes.

27. United States v. Jenkins, 420 U.S. 358, 363-64 (1975); United States v. Wilson, 420 U.S. 332, 337-39 (1975).

28. A few cases involving the limits of the double jcopardy clause did arise prior to the Criminal Appeals Act of 1970. See, e.g., Fong Foo v. United States, 369 U.S. 141 (1962); Kepner v. Unitcd States, 195 U.S. 100 (1904).

29. 420 U.S. 377 (1975).

30. 420 U.S. 358 (1975).

31. 420 U.S. 332 (1975).

32. United States v. Jenkins, 420 U.S. 358, 370 (1975).

33. Where the jury returns a verdict of not guilty, the government may not appeal. See, e.g., United States v. Wilson, 440 U.S. 332, 352 (1975); Fong Foo v. United States, 369 U.S. 141 (1962). 
appeal, as reversal and remand would require further proceedings to resolve factual issues.

The further proceedings test adequately protects the defendant's double jeopardy interests. It offers no opportunity for a prosecutor to convert his appeal right into a weapon for successive, harrassing prosecutions. ${ }^{34}$ A successful government appeal of the judge's postverdict dismissal merely results in remstatement of the verdict and terminates the prosecution. The defendant is spared the anxiety and burdens of retrial. The appeal itself does subject the defendant to anxiety and expense, but this is equally true of the government's well-established right to appeal to a higher appellate court when a defendant's appeal results in reversal of a conviction. The double jeopardy clause protects the defendant only froin appearing before a second trier of fact, not from undergoing appellate proceedings. ${ }^{35}$

As the prosecution will have no opportunity to conduct a second trial, the further proceedimgs test protects the defendant's interest in avoiding wrongful conviction. Of course, appeal may result in reversal of the dismissal and remstatement of the jury conviction, but the risk of wrongful conviction does not seein to be increased by the appeal. The defendant can appeal the appellate reversal if the internnediate appellate court interprets the law incorrectly.

Finally, the further proceedings test does not infringe on the defendant's jury nullification interest. Appeal of a pretrial dismissal does not affect the interest because dismissal occurs before the jury is impaneled. Likewise, appeal of a postverdict disımissal does not infringe on the jury nullification interest as the jury by convicting has chosen not to exercise its nullifying power.

The weakness of the further proceedings test is that it inadequately protects the government's interest in convicting guilty defendants. When a trial court dismisses charges midtrial, the test precludes appellate review. Thus, a trial judge's erroneous interpretation of the law could result in the unnecessary release of guilty persons. While erroneous legal interpretations followed by a jury acquittal are properly immune from appellate review because of the jury nullification principle, ${ }^{36}$ the further proceedings test infringes on the government's

34. See Comment, Double Jeopardy Limitations on Appeals by the Government in Criminal Cases, 80 Dick. L. Rev. 525, 533-34 (1976).

35. See United States v. Wilson, 420 U.S. 332, 345 (1975):

Although review of any ruling of law discharging a defendant obviously enhances the likelihood of conviction and subjects him to continuing expense and anxiety, [he] has no legitimate claim to benefit from an error of law when that error could be corrected without subjecting him to a second trial before a second trier of fact.

36. See text acconpanying notes 18-21 supra. 
legitimate prosecutorial interest by barring appeal even when jury nullification has not occurred.

\section{B. The Scott Test}

In United States v. Scott, ${ }^{37}$ the Supreme Court expressly overruled Jenkins, which had adopted the further proceedings test. ${ }^{38}$ The Scott Court held that the double jeopardy clause does not prohibit government appeal from a defendant-initiated inidtrial dismissal granted on grounds unrelated to factual innocence.

Defendant Scott was charged in a three-count indictment with the distribution of narcotics. He was tried before a jury in federal district court. Before trial and twice during trial Scott moved to dismiss the first two counts on the ground that his defense had been prejudiced by premdictment delay. ${ }^{39}$ The judge granted the motion at the close of the evidence. ${ }^{40}$ The Sixth Circuit, applying the further proceedings test, dismissed the government's appeal, as further procecdings devoted to the resolution of factual issues would be required on reversal and remand. ${ }^{41}$ The Supreme Court reversed, holding that the government may appeal from a midtrial dismissal requested by the defense and granted on grounds unrelated to factual innocence. ${ }^{42}$

Writing for a five-justice majority, Justice Rehnquist explained that in adopting the further proceedings test, the court had "placed an unwarrantedly great emphasis on the defendant's right to have his guilt decided by the first jury impaneled to try him so as to include those cases where the defendant himself seeks to terminate the trial before verdict on grounds unrelated to factual guilt or innocence."43 The majority reasoned that reprosecution does not norinally violate the double jeopardy clause when a defendant successfully moves for a mistrial. By analogy, a government appeal and possible reprosecution after the defendant successfully moves for dismissal of one or more counts should

37. 437 U.S. 82 (1978).

38. Id. at 101.

39. The defense of preindictment delay is grounded in the due process clause of the fifth amendment. See United States v. Marion, 404 U.S. 307, 324-25 (1971). In Scott there had been a seven-month delay between the alleged criminal activity and Scott's indictment. United States v. Scott, 437 U.S. at 84 (1978).

40. 437 U.S. at 84 . The judge submitted the third count to the jury, which returned a verdict of not guilty. $I d$.

41. Umited States v. Scott, 544 F.2d 903 (6th Cir. 1976), rev'd, 437 U.S. 82 (1978).

42. 437 U.S. at 101. Justice Brennan, joined by Justices White, Marshall, and Stevens, dissented on the grounds that the majority's distinction between "true acquittals" and other final judgments favorable to the accused bore no relationship to double jeopardy principles and that the majority's definition of "acquittal" was overly restrictive and incapable of principled application. Id. at 103 (Brennan, J., dissenting).

43. Id. at 87. 
not offend the clause. ${ }^{44}$ In either case the defendant could be said to be electing to "forego his valued right to have his guilt or innocence determined before the first trier of fact." 45 The Court held that the important consideration for double jeopardy purposes is that the defendant " "retain primary control over the course to be followed" " in the event of an error in the proceedings. ${ }^{46}$

To justify abandoring the further proceedings test, the Court stated that the test had already been undermined by United States $v$. Martin Linen Supply Co. ${ }^{47}$ and Lee v. United States. ${ }^{48}$ In Martin Linen, the defendant successfully inoved for a judgment of acquittal under Federal Rules of Criminal Procedure 29(c), which permits a trial judge to enter a judgment of acquittal after the jury returns a verdict of guilty or if the jury fails to reach a verdict. ${ }^{49}$ The Court held that a Rule 29(c) ruling is an acquittal and is therefore protected by the double jeopardy clause. ${ }^{50}$ The $S$ cott Court reasoned that the decision marked a step away from the further proceedings test toward an "acquittal" test, and that under Martin Linen appeal is barred only when the trial judge's ruling is in some sense an "acquittal"- " "a resolution [in the defendant's favor], correct or not, of some or all of the factual elements of the offense charged." "51

In Lee, the Court permitted a second trial after a dismissal which the Court found to be "functionally indistinguishable from the declaration of a mistrial." 52 The Scott majority argued that Lee demonstrated that the dismissal of an indictment may im some cases be treatcd on the saine basis as the declaration of a mistrial. ${ }^{53}$ The Court reasoned that the dismissal in Scott did not constitute an "acquittal." Instead, the

\footnotetext{
44. Id. at $93-101$.

45. Id. at 93 .

46. Id. at 93-94 (quoting United States v. Dinitz, 424 U.S. 600, 609 (1976)).

47. 430 U.S. 564 (1977).

48. 432 U.S. 23 (1977).

49. FED. R. CRIM. P. 29(c) provides for the post-trial motion for acquittal:
}

If the jury returns a verdict of guilty or is discharged without having returned a verdict, a motion for judgment of acquittal may be made or renewed within 7 days after the jury is discharged or within such further tine as the court may fix during the 7-day period. If a verdict of guilty is returned the court may on such motion set aside the verdict and enter judgment of acquittal. If no verdict is returned the court may enter judgment of acquittal. It shall not be necessary to the making of such a motion that a similar motion has been nade prior to the submission of the case to the jury.

50. 430 U.S. at 570 .

51. 437 U.S. at 97 (quoting United States v. Martin Limen Supply Co., 430 U.S. at 571).

52. 432 U.S. at 31 . In Lee, the district judge granted the defendant's inotion to disiniss a defective inforination at the conclusion of all the evidence. Thereafter, the defendant was charged with the same offense in a valid indictment and was convicted. The Supreme Court rejected the defendant's double jeopardy claim, holding that, as the dismissal was made in contemplation of further prosecution, it was functionally indistimguishable from a mistrial. Because the disinissal had been granted in response to a defense motion, reprosecution was not barred.

53. 437 U.S. at 94. 
Court found it functionally equivalent to a mistrial, because a dismissal for preindictment delay represents a legal judgment-not a factual finding - "that a defendant, although criminally culpable, may not be punished because of a supposed constitutional violation." 54 Since a mistrial granted on a defendant's motion would not bar retrial, the Court concluded that the double jeopardy clause should not bar government appeal of the dismissal granted on Scott's motion. ${ }^{55}$

Scott is based on two theories: that by moving for a midtrial dismissal, a defendant elects to forego his right under the double jeopardy clause to have the first trier of fact determine his guilt or innocence; and that the double jeopardy clause protects a defendant from a second trial only if he has been acquitted im the first. Both theories are unsound.

\section{The "Election" Theory}

The Scott Court reasoned that "the Double Jeopardy Clause, which guards agaimst Government oppression, does not reheve a defendant from the consequences of his voluntary choice."56 Thus, the defendant who "deliberately choos[es] to seek termination of the proceedings against him on a basis unrelated to factual guilt or innocence . . . suffers no mjury cognizable under the Double Jeopardy Clause if the Government is permitted to appeal from such a ruling of the trial court in favor of the defendant."'57 In support of this argument, the Court relied on the analogy to mistrials, where retrial is permitted on the theory that a defendant's mistrial motion represents a deliberate election to forego double jeopardy protection..$^{58}$ It is not at all clear, however; that the mistrial election rationale should apply in the dismissal context.

Mistrials and dismissals are conceptually and functionally different. A mistrial simply terminates a procedurally faulty trial. When a defendant moves for mistrial, he is aware that the granting of his request will result in a new trial. Although he would prefer a single trial free of error, that choice is no longer available. He therefore prefers a second trial over an unjust conviction. In contrast, when a trial court

54. Id at 98 .

55. Id. at 99 .

56. Id. Despite this language, it appears that the voluntariness of the defendant's choice will be irrelevant under $S$ cott. Scott sought to treat dismissals on the same basis as mistrials. Since in the mistrial context the defendant's inotion need not ineet the requireinents of a voluntary, knowing, intelligent waiver, see United States v. Dinitz, 424 U.S. 600, 609 \& n.11 (1976), the defendant's dismissal notion probably need not ineet the requirements of the "waiver" doctrine. But $c f$. Schneckloth v. Bustamonte, 412 U.S. 218, $237-38$ (1973) (dictun) (waiver of double jeopardy rights nust be knowing and intelligent).

57. 437 U.S. at $98-99$.

58. Id. at 93 . 
dismisses a case, it makes a final resolution of factual or legal issues in favor of the defendant. When a dismissal is granted, the court and the defendant contemplate that there will be no further proceedings. ${ }^{59}$ Of course, after $S$ cott, it can be argued that a defendant seeking a dismissal is or should be aware of the risk of appellate reversal and a new trial. This, however, is analogy by fiat-the Court declares that the two situations are similar, and therefore they become so.

More importantly, the election doctrine is consistent with the purposes underlying the double jeopardy clause in the mistrial context but not in the dismissal context. When judicial or prosecutorial error occurs, the defendant may opt to seek a mistrial because he fears that "a contmuation of the tainted proceeding would result in a conviction followed by a lengthy appeal and, if a reversal is secured, by a second prosecution." 'D As the Supreme Court observed in United States $v$. Dinitz, in these circumstances a defendant's mistrial request is actuated by interests similar to those served by the double jeopardy clause- "the avoidance of the anxiety, expense, and delay occasioned by multiple prosecutions." 61 In contrast, under $S$ cott, a defendant's request to disimiss does not have consequences consistent with the interests protected by the double jeopardy clause. If a defendant's dismissal motion is granted, there is no immediate new trial. Rather, under Scott, a successful dismissal motion may be followed by a lengthy appeal and, if reversal is secured, by a second prosecution -in short, the very "expense, anxiety, and delay" the Dinitz Court sought to avoid. Thus, the election rationale is inappropriate in the dismissal context.

\section{The "Acquittal" Theory}

Scott held that appeal of a defendant-mitiated midtrial dismissal is barred only when the trial court's ruling is an "acquittal"- $a$ " "ruling of the judge... [ [that] actually represents a resolution [in the defendant's favor] ... . of some or all of the factual elements of the offense

59. The trial judge's label is not conclusive on the issue of double jeopardy. See Downum v. United States, 372 U.S. 734 (1963). The Scott Court relied on Downum to support its statement that " $[t]$ he fact that the trial judge contenuplates that there will be a new trial is not conclusive on the issue of double jeopardy." 437 U.S. at 92 . What the Court failed to poimt out is that Downum had previously been applied only to curb a judge's abuse of discretion in declaring a mistrial sua sponte. See, e.g., Fleming v. United States, 332 F.2d 23, 25 (1st Cir. 1964). The trial judge's contemplation of reprosecution was considered decisive when the error favored the prosecution. See, e.g., Lee v. United States, 432 U.S. 23 (1977). Thus, before Scott, courts applied Downum to protect a defendant's double jeopardy interests from unwarranted judicial declaration of mistrial without the defendant's consent. The Scout Court applied it to protect the government's interest in conviction at the expense of the defendant's double jeopardy interests.

60. United States v. Dinitz, 424 U.S. 600,608 (1976).

61. Id 
charged." "62 This holding is not required by precedent, and it inadequately protects the defendant's double jeopardy interests.

That the double jeopardy clause prohibits appeal of an acquittal is a well-estabhished doctrine. ${ }^{63}$ The Scott Court's arguinent that Martin Linen establishes that the clause protects only acquittals, however, is not convincing. Although the Martin Linen Court rested its holding on the unappealability of acquittals, it does not follow that the Court meant to protect only acquittals or that it meant to reject the further proceedings test. In Martin Linen, the Court addressed the narrow issue whether a judgment of acquittal granted pursuant to Federal Rules of Criminal Procedure 29(c) after the jury failed to reach a verdict constitutes an acquittal for double jeopardy purposes. The Court held that it does, observing that the judge's disposition of the case was an acquittal "in substance as well as form," since it resolved elements of the offense in the defendant's favor. ${ }^{64}$ Martin Linen should not be read as undermining the further proceedings test, however, as the Court's discussion of that test was not necessary to its holding. Finding that the Rule 29(c) acquittal was a "real" acquittal sufficed to invoke double jeopardy protection. The Martin Linen Court thus had no reason to address the issue of whether the double jeopardy clause protects only acquittals. Scott's reading of Martin Linen as a deliberate step away froin the further proceedings test in favor of an acquittal test is thus unsupported by the Martin Linen opinion itself.

Although the Court's justification for abandoning the further proceedings test is not persuasive, the $S$ cott acquittal test does have the merit of protecting the government's interest in convicting guilty defendants. A defendant whose case has been disinissed inidtrial on erroneous legal grounds will not go free; only when the dismissal is based on factual innocence is the defendant protected froin further prosecution.

The weakness of the Scott test is that it protects the government's interest at the expense of the defendant's double jeopardy interests. The $S$ cott test fails to protect the defendant froin the ordeal of inultiple trials. This is clearly illustrated in a case where the trial judge delays ruling on a pretrial dismissal inotion until midtrial, either because of judicial error or because the validity of the defendant's objections can be demonstrated only by presenting facts at trial. In these situations, and in any case where a midtrial dismissal is based on legal grounds, Scott requires a defendant to attempt twice to persuade a factfinder of

62. 437 U.S. at 97 (quoting United States v. Martin Linen Supply Co., 430 U.S. at 571).

63. See, e.g., United States v. Wilson, 420 U.S. 332, 352 (1975); Fong Foo v. United States, 369 U.S. 141, 143 (1962).

64. United States v. Martin Linen Supply Co., 430 U.S. at 571-72. 
his version of the facts. He must endure delay, additional expense, and a prolonged period of unresolved guilt-the very burdens the double jeopardy clause is meant to prevent.

The defendant's second interest, protection against an increased risk of being convicted although innocent, is also inadequately protected by the Scott test. The test affords the prosecution a second opportunity to obtain a conviction after it has already viewed the defendant's trial strategy and has had an opportunity to strengthen its own presentation. These advantages, coupled with the possibility that the defendant's resistance and resources have been depleted by the prior trial and appeal, increase the chances of a wrongful conviction.

The defendant's interests in avoiding multiple trials and the risk of wrongful conviction are further undermined by the $S$ cott test because it nakes motions for dismissal a target for manipulation. An unscrupulous prosecutor might intentionally provoke a defense motion for dismissal to obtain a more favorable jury or end a trial going badly ${ }^{65} \mathrm{~A}$ prosecutor could provoke a defense dismissal motion by revealing in the middle of trial a supposed error in the institution of proceedings. ${ }^{66}$ On appeal, the prosecutor would present arguinents and legal precedent he purposely omitted when superficially opposing the motion below. After appellate reversal, he could retry the case. ${ }^{67}$

Mamipulation by the trial judge is also possible, although probably less likely. An unscrupulous judge could provoke a dismissal motion or delay granting a pretrial dismissal motion until midtrial to aid the prosecution. The scheme would require, however, that the judge dismiss on an invalid legal ground to set the stage for appellate reversal. Most judges would probably be unwilling to risk their reputations by trying to increase their rate of appellate reversal.

The Scott test arguably does not infringe on the defendant's jury nullification interest, however. At least in those cases where the prosecution does not dehiberately provoke a midtrial dismissal motion, a defendant who seeks a dismissal, knowing that if the motion is granted the proceedings will terminate before the question of guilt or innocence goes to the jury, foregoes his right to complaim that the jury might have exercised its nullification prerogative.

In addition to inadequately protecting the defendant's interests in

65. See Comment, supra note 34 , at 540 .

66. For example, he might introduce evidence revealing a supposed error such as a defective indictment, lack of jurisdiction, preindictment delay, denial of speedy trial, or failure to disclose exculpatory information.

67. In this situation, as in the mistrial context, the double jeopardy clause should be held to bar retrial where the defendant can show that the prosecution intentionally provoked the defendant's dismissal unotion. See United States v. Scott, 437 U.S. at 94 (quoting United States v. Dinitz, 424 U.S. 600, 611 (1976)). 
avoiding the ordeal of multiple trials and the risk of wrongful conviction, the Scott test gives rise to two other problems: the difficulty of producing a consistent criminal law doctrine because of jurisdictional differences in categorizing a dismissal as factual or legal, and the administrative difficulty of determining the basis for the trial court's decision.

Scott bars appeal of midtrial dismissals based on factual grounds but not those based on legal grounds. ${ }^{68}$ It provides little guidance, however, as to how this distimction should be drawn. This issue, as Justice Brennan points out in his dissent, is especially troublesome in defenses which may be viewed as either factual or legal, such as entrapment or insanity. ${ }^{69}$ Some jurisdictions view entrapment as a factual defense, defeating the mens rea element of the charged offense. ${ }^{70}$ Others view it as a policy-oriented legal defense meant to deter police nnisconduct. ${ }^{71}$ Likewise, the insanity defense may be viewed either as a factual defense defeating the mens rea element, ${ }^{72}$ or as a legal defense relieving a defendant of criminal liability even though all of the elements of the crime could be established beyond a reasonable doubt. ${ }^{73}$

68. The fundamental question is whether this distinction should make any difference for double jeopardy purposes. Professor Cooper provides an imteresting example for analyzing this question. See Cooper, Government Appeals in Criminal Cases: The 1978 Decisions, 81 F.R.D. 539, 541 (1979). Suppose, in a prosecution for armed robbery, the defendant inoves for dismissal at the close of the government's evidence on two grounds. One is prejudicial preindictment delay. The other is failure to submit any evidence that the hammer was cocked on the loaded automatic pistol the defendant was carrying. If dismissal is granted on the ground of premdictment delay, the government may appeal. On the other hand, it cannot appeal from a dismissal resting on the ground that the government failed to prove that the hammer was cocked, since that is an essential element of the offense charged. This is true even though the trial court is incorrect in concluding that this fact is an essential element of the offense.

The defendant's double jeopardy interests seen identical in both cases. Appeal from both rulings would involve the same risk of retrial with its accompanying emotional and financial burdens. The defendant's interest in finality seems identical; in neither case does the ruling represcnt that the trial judge resolved a factual element surrounding one of the true elements of the offense in the defendant's favor. Becanse both defenses can usually be estabhshed only at trial on the merits, the defendant is forced to expose his trial strategy to the prosecution, which increases the risk of wrongful conviction in the second trial. In neither case does the defendant have an interest in jury nullification, simce he elected not to go to the jury. Scott offers no satisfactory explanation why the two defenses in this example should trigger such different double jeopardy results.

69. 437 U.S. at 112-15 (Breunan, J., dissenting).

70. See Hampton v. United States, 425 U.S. 484, 488-89 (1976); United States v. Russell, 411 U.S. 423,435 (1973).

71. See Park, The Entrapment Controversy, 60 MiNs. L. Rev. 163, $171-76$ (1976). Justice Brennan suggests that $S$ cott may lead to double jeopardy distinctions that depend on the substantive law of a particular jurisdiction. 437 U.S. at 115 (Brennan, J., dissenting).

72. See United States v. Currens, 290 F.2d 751, 774 (3d Cir. 1961); Cuomo, Mens Rea and Status Criminality, 40 So. CAL. L. REv. 463, 470-71 (1967); Goldstein \& Katz, Abolish the "Insanity Defense"-Why Not?, 72 Yale L.J. 853, 864 (1963); Sayre, Mens Rea, 45 Harv. L. Rev. 974, 989 (1932).

73. See Goldstein \& Katz, supra note 72 , at 854. 
The Court dismisses in a footnote the practical difficulty of distinguishing between factual and legal dismissals, pointing out that courts must make similar judgments in other circuinstances. ${ }^{74}$ The Court's own discussion of the insanity defense, however, illustrates the problein. The Court concludes that insanity is "essentially [a] factual defense"75 even if it is considered a legal justification for otherwise criminal acts. The Court reasons that to find a defendant insane, the trier of fact must be convinced that factual evidence of insanity "provides a legally adequate justification."76 The Court does not explain, however, why the saine argunient does not apply to the $S$ cott facts-a dismissal for preindictunent delay-where the lower court also had to evaluate factual evidence to determine that delay had occurred, that it was excessive, and that it ineant Scott could not legally be punished.

As Justice Brennan's dissent points out, ${ }^{77}$ Scott's uncertain distinction between legal and factual dismissals makes the test a very poor guide to lower courts in cases dismissed on grounds which could be construed as either legal or factual. It fails also to recognize that a defendant's double jeopardy interests should not turn on whether a jurisdiction happens to view a particular defense as factual rather than legal.

Moreover, in applying the Scott test, there is often a practical problem in determining the exact grounds for the dismissal. This problem can be particularly difficult in a bench trial, where the judge both finds the facts and rules on the law. If the judge prepares special findings of fact, it may often be possible by sifting those findings to determine the precise grounds for the dismissal. But this is not always true. In Jenkins, for example, the district judge filed written findings of fact and conclusions of law, ${ }^{78}$ but the Supreme Court could not say with assurance whether the dismissal involved a resolution of factual issues or not. ${ }^{79}$ Determining the grounds for dismissal in a bench trial would be substantially more difficult in cases where no special findings of fact were made, but it seems likely that after $S$ cott at least one of the parties will request such findings. ${ }^{80}$ Even if written findings are available, they

74. 437 U.S. at $98 \mathrm{n} .11$.

75. Id. at 97.

76. Id. at $97-98$.

77. Id. at 112-15 (Brennan, J., dissenting).

78. United States v. Jenkins, 420 U.S. 358, 362 (1975).

79. Id at 367-70. The inajority in Scott admitted this fact but dismissed its importance on the ground that in Jenkins the Court was inquiring whether the trial proceedings had terminated "in the defendant's favor" and whether "further proceedings . . . devoted to the resolution of factual issues going to the elemnents of the offense charged, would have been required on reversal and reinand," and not whether the district court had nuade an erroneous interpretation of law or had resolved controlling factual issues in favor of the defendant. 437 U.S. at 97 n.9.

80. FED. R. CRIM. P. 23(c) provides: 
may be ambiguous ${ }^{81}$ and could require time-consuming appellate scrutiny. In the meantime, the government's right to appeal is uncertain, and the defendant is left to wonder whether he will have to endure another trial. These practical problems tend to foster the very anxiety and risk of prolonged proceedings the double jeopardy clause is designed to avoid.

The foregoing analysis reveals that while the $S$ cott test more adequately protects the government's interest in convicting guilty defendants than did the further proceedings test, it does so at the expense of a defendant's interests im avoiding the ordeal of multiple trials and in avoiding an increased risk of wrongful conviction. Furthermore, Scott's distinction between legal and factual dismissals comphicates double jeopardy analysis, and therefore will likely generate unpredictable and nonuniform results at a higher administrative cost. Finally, $S c o t t$ leaves open the potential for abuse by providing incentives to unscrupulous prosecutors and judges to provoke dismissal when a trial is not going as they would like.

111

\section{A Proposal: The Before-AND-After Approach}

A before-and-after jeopardy approach to dismissals would solve nearly all the problems of both the further proceedings test and Scott's aquittal test. Under this system, a trial judge could dismiss charges before and after jeopardy, but not during the trial itself. ${ }^{82}$ The government could appeal all dismissals. This system protects a defendant's double jeopardy interests while preserving the government's interest in convictimg guilty defendants. 1t would avoid the necessity of a timeconsuming and unpredictable appellate search for an acquittal, and it

In a case tried without a jury the court shall make a general finding and shall in addition, on request made before the general finding, find the facts specifically. Such findings may be oral. If an opinion or memorandum of decision is filed, it will be sufficient if the findings of fact appear therein.

The trial judge may also make such findings sua sponte. See, e.g., Sullivan v. United States, 348 U.S. 170, 174 (1954).

81. See, e.g., Umited States v. Bowline, 593 F.2d 944 (10th Cir. 1979) (court divided on the issue whether the trial court's dismissal was based on a defective count or a variance between the count and the evidence at trial).

82. The Scott Court recommeuded the voluntary adoption of this procedure as a way to "reconcile the public interest in the Government's right to appeal from an erroneous conclusion of law with the defendant's interest in avoiding a second prosecution." 437 U.S. at 100 n.13. The Court added, however, that it was not suggesting that "a midtrial dismissal of a prosccution, in response to a defense motion on grounds unrelated to guilt or innocence, is necessarily improper. Such rulings may be necessary to terminate proceedings marred by fundamental error. But where a defendant prevails on such a motion, he takes the risk that an appellate court will reverse the trial court." Id. This Comment argues that the before-and-after approacli should be mandatory, rather than increly recommended. 
would replace current double jeopardy law with a system of consistent and easily applied rules.

Under the proposed approach, the defendant could still move for pretrial dismissal. If the judge enters a dismissal before trial commences, the government may appeal. Federal Rules of Criminal Procedure $12(b)^{83}$ permits a defendant to raise certam defenses or objections before trial. The trial court can dismiss before trial if a failure of proof or a conclusive defense appears in pretrial stipulations, if a defect exists in the charging instrument or institution of proceedings, or if the defendant establishes another defense capable of determination without trial. ${ }^{84}$ Because jeopardy has not attached and the parties have not yet presented their evidence to the trier of fact, the government should be allowed to appeal froin the pretrial dismissal. ${ }^{85}$ No distimction between dismissals based on factual assessments and those based on legal grounds is necessary.

If a dismissal inotion camiot be ruled on prior to trial, however, under the proposed approach the trial judge must delay ruling on the Inotion until after the jury returns a guilty verdict or, in a bench trial, until after the judge finds guilt. ${ }^{86}$ The government could appeal a postverdict dismissal, as appellate reversal and reinand requires only that the jury's verdict or court's finding of guilt be reinstated. ${ }^{87}$

The before-and-after approach adequately protects a defendant's double jeopardy interests. He will not be subject to the ordeal of inultiple trials because he will never face the prospect of a second trial following dismissal. Since the prosecution has no opportunity to miprove its presentation in a second trial, the proposed approach avoids the $\mathrm{m}$ creased risk of wrongful conviction that exists under an approach which allows nore than one trial. The before-and-after approach elim-

83. FED. R. CRIM. P. 12(b) provides:

Any defense, objection, or request which is capable of determination without the trial of the general issue may be raised before trial by motion. Motions may be written or oral at the discretion of the judge. The following must be raised prior to trial:

(1) Defenses and objections based on defects in the institution of the prosecution; or

(2) Defenses and objections based on defects in the indictment or information (other than that it fails to show jurisdiction in the court or to charge an offense which objections shall be noticed by the court at any time during the pendency of the proceedings); or

(3) Motions to suppress evidence; or

(4) Requests for discovery under Rule 16; or

(5) Requests for a severance of charges or defendants under Rule 14.

84. Comment, Double Jeopardy and Government Appeals of Criminal Dismissals, 52 TEX. L. Rev. 303, 337 (1974).

85. See Serfass v. United States, 420 U.S. 377, 389 (1975).

86. Of course, if the factfinder acquits the defendant, a ruling on the dismissal motion is unnecessary.

87. See notes 34-35 and accompany text supra. 
inates the potential for judicial and prosecutorial abuse possible under $S c o t t$. Because of the blanket rule barring all midtrial dismissals, a prosecutor could no longer provoke a dismissal motion to obtain a second trial. ${ }^{88}$ Neither could a trial judge delay ruling on a pretrial dismissal motion until midtrial to harass a defendant or help the prosecution by setting the stage for a second trial. Finally, the beforeand-after approach insures that once jeopardy attaches a defendant will not be deprived of his right to have the first jury decide whether to exercise its nullification prerogative.

The before-and-after approach also protects the government's interest in convicting guilty defendants better than the Scott test. It eliminates the incentive defendants have under Scott to delay a dismissal motion based on factual grounds until midtrial, in the hope that if dismissal is granted it will be insulated from appellate review. It also offers a greater opportunity to correct errant trial judges and promote uniform development of the criminal law by allowing appellate review of all dismissals, not inerely soine of thein.

At the saine time, the before-and-after approach simplifies appellate review by eliminating the requirement that the appellate court search the trial record for an acquittal. The approach also eliminates the inconsistency and uncertainty created by the sometimes arbitrary and elusive distinction between factual and legal defenses. ${ }^{89}$ No such distinction need be inade for double jeopardy purposes under the proposed approach, because the further proceedings test is always satisfied and there is never a need for a new trial. ${ }^{90}$

88. See United States v. Scott, 437 U.S. 82, 94 (1978) (quoting United States v. Dinitz, 424 U.S. 600, 611 (1976)) (" ‘T]he Double Jeopardy Clause does protect a defendant against governmental actions intended to provoke mistrial requests and thereby to subject defendants to the substantial burdens imposed by inultiple prosecutions." "). Scott's citation of this rule and its heavy reliance on mistrial doctrine suggest that governmental manipulation causing untimely disimissals will be treated similarly to governmental manipulation causing mistrials.

89. See notes 68-77 and accompanying text supra.

90. The Scott opinion itself reiterated the assumption in United States v. Jenkins, 420 U.S. 358,365 (1975), that even a judgment of acquittal could be appealed where no retrial would be needed on remand:

In Jenkins we had assumed that a judgment of acquittal could be appealed where no retrial would be needed on remand:

"When this principle is applied to the situation where the jury returns a verdict of guilt but the trial court thereafter enters a judgment of acquittal, an appeal is permitted. In that situation a conclusion by an appellate court that the judgment of acquittal was improper does not require a criminal defendant to submit to a second trial; the error can be corrected on remand by the entry of a judgment on the verdict." [420 U.S. at 365]. Despite the Court's lieavy emphasis on the finality of an acquittal in Martin Linen and Sanabria v. United States, [437 U.S. 54 (1978)], neither decision explicitly repudiates this assumption. Sanabria, [437 U.S. at 75]; Martin Linen, 430 U.S. at 569-570.

437 U.S. at 91 n.7.

Circuit courts of appeals decisions after Scott also follow this reading of Jenkins. See United States v. Blasco, 581 F.2d 681, 683 (7th Cir. 1978); United States v. Jones, 580 F.2d 219, 221 n.3 
Commentators praise the further proceedings test as offering a uniform and consistent basis for double jeopardy analysis. ${ }^{91}$ Scott, however, reflects the Court's dissatisfaction with mechanical rules that allow a trial judge to terminate a trial im favor of a defendant on legal grounds, but deny appellate review of that legal determination. The before-and-after approach preserves the clarity and simplicity of the further proceedings test without shielding the trial judge's dismissals from appellate review.

Finally, the before-and-after approacli more adequately serves the policies underlying the prohibition against double jeopardy because, like the double jeopardy clause itself, it inakes no mquiry into the defendant's culpability. Scott's acquittal test attempts to distmguish between those defendants whose factual innocence has been established and those whose innocence lias not been proved; it extends double jeopardy protection only to the former. Thus, under Scott, a defendant's double jeopardy protection varies according to his guilt or innocence. The fifth amendinent is designed to protect the guilty as well as the innocent from the burdens of multiple trials, regardless of the miportance of the government's interest in convicting the guilty. ${ }^{92}$ The before-and-after approacli protects the double jeopardy imterests of all defendants, guilty or innocent, without subordinatimg the government's interest.

The before-and-after approach miglit, lowever, invite abuse by soine defendants. A defendant who recognizes grounds for a dismissal motion before trial might be tempted to delay the motion until after trial to benefit from the chance of an acquittal. If lie is acquitted, there is no need for the motion. If convicted, the defendant can move for dismissal. This strategic delay has three undesirable consequences. First, had the defendant successfully moved for dismissal before trial, the prosecution could liave cliosen to appeal the dismissal. Alterna-

(6th Cir. 1978); United States v. Clemones, 577 F.2d 1247, 1255 (5th Cir. 1978); United States v. Dreitzler, 577 F.2d 539, 544 \& n.7 (9th Cir. 1978). Professor Cooper argues strongly for allowing appeal from a trial court acquittal after a jury verdict of guilty. See Cooper, supra note 68, at 558 .

91. See, e.g., Westen \& Drubel, supra note 12, at 148; Comment, Double Jeopardy and Government Appeals in Criminal Cases, 12 ColUM. J.L. \& Soc. ProB. 295, 350 (1976); Note, Double Jeopardy-Government's Right to Appeal a Midtrial Dismissal, 1978 B.Y.U. L. REv. 742, 749; Note, Twice in Jeopardy; Prosecutorial Appeals of Sentences, 63 VAND. L. REv. 325, 342-47 (1977).

92. A criminal trial is in part a search for truth. But it is also a system designed to protect "freedom" by insuring that no one is criminally punished unless the State has first succeeded in the admittedly difficult task of convincing a jury that the defendant is guilty. That task is made more difficult by the Bill of Rights, and the Fifth Amendment may be one of the most difficult of the barriers to surmount. The Framers decided that the benefits to be derived from the kind of trial required by the Bill of Rights were well worth any loss in "efficiency" that resulted. Their decision constitutes the final word on the subject, absent some constitutional amendment. That decision should not be set aside....

Williams v. Florida, 399 U.S. 78, 113-14 (1970) (Black, J., dissenting). 
tively, if the error was correctable, as in the case of an incomplete indictment, the prosecution could have chosen to correct the error and recharge the defendant. But if the defendant delays the dismissal inotion until after the verdict, the prosecution has no opportunity to correct the error. Its only avenue is to appeal the dismissalunsuccessfully, if the dismissal was proper. Second, if the error is not correctable, as in the case of preindictinent delay or denial of the right to a speedy trial, dismissing before trial saves government and court resources. Third, if the defendant does not move for pretrial dismissal, and the prosecutor discovers the error during trial, the prosecutor must nevertheless proceed with the trial, knowing that the defendant will move to dismiss the charges if the jury returns a guilty verdict and that a potentially lengthy appeal will be needed to remstate the verdict. Thus, the prosecutor may lose his incentive to hitigate forcefully, which increases the chance of an improper acquittal. ${ }^{93}$

Requiring the defendant to raise certain defenses before trial would protect the government's interest in convicting the guilty in an error-free proceeding, without undue hardship on the defendant. It is therefore important that the mandates of Federal Rules of Criminal Procedure 12(b), ${ }^{94}$ which provides that certain defenses are waived if not raised prior to trial, be strictly enforced to prevent manipulation by defendants. Even the dissenters in Scott conceded that it might not be objectionable to hinge double jeopardy consequences on a defendant's failure to take advantage of an opportunity to inove for dismissal before trial. ${ }^{95}$

Another potential problem with the before-and-after approach is that a trial judge forced to delay his ruling on a dismissal motion until after the verdict might be unwilling to set aside the verdict. This problem could be easily avoided by requiring the judge to rule on the motion in writing and deliver it unannounced to the court clerk before the jury returus its verdict, to be read by the court clerk after a verdict of guilty is returned.

The costs of the before-and-after approach are slight in comparison to its benefits. The approach sacrifices some judicial econouny in

93. This problem occurs under the before-and-after approach in cases where clcar grounds for dismissal become apparent during the trial. The government may lose its imcentive to prosecute vigorously, and some judicial resources are spent unnecessarily. However, since what is clear error is not always so clear, and since most midtrial dismissals involve some risk of reversal, it seems more equitable to require the completion of those trials rather than to allow the manipulation, unpredictability, and involuntary retrial which are possible under $S c o t t$.

94. See note 83 supra.

95. "[1]t perhaps might not be objectionable to permit retrial of a defendant whose first trial was terminated on the basis of a midtrial ruling that could-because it did not depend on the facts adduced at trial-have been raised before jeopardy attached, see Serfass $v$. United States, [420 U.S. 377, 394 (1975)] . . . ." 437 U.S. at 112 (Brennan, J., dissenting). 
favor of double jeopardy protection. Because the approach does not permit the dismissal of any count at the close of the government's evidence, the defendant must present a defense and the jury must be imstructed on counts as to which there is insufficient evidence or a defect prohibiting conviction. This is time-consuming, particularly im a large, multiple-defendant trial. This problem can be partially controlled, however, through existing procedural devices. If the imsufficiency of the evidence or the procedural defect becomes apparent during preliminary proceedings, the court can dismiss the count prior to trial. If the insufficiency of the evidence becomes apparent during the presentation of evidence at trial, the trial judge can grant a judgment of acquittal on that count under Federal Rules of Criminal Procedure 29(a). ${ }^{96}$

\section{CONCLUSION}

The Scott test suffers from numerous weaknesses, both theoretical and practical. While the $S$ cott test protects the government's interest im convictimg guilty criminals better than did prior law, it inadequately protects a defendant's double jeopardy interests. It permits soine defendants to be subjected to trial twice because of an ill-timed dismissal motion by defense counsel. It permits prosecutorial and judicial mamipulation designed to give the prosecution a second opportunity to convict, increasimg the risk of wrongful conviction. Scott's adoption of the election rationale from the mistrial context is inappropriate, since the theoretical justification underlying the election rationale in the mistrial context-that it serves double jeopardy policies by avoiding expense, anxiety, and delay-is absent im the dismissal context. Nor is the acquittal rcquirement supported by precedent, as the Scott Court indicates. Finally, the Scott test severely complicates double jeopardy analysis by requiring an appellate court to differentiate between legal and factual defenses and to search through a trial record for a ruling constituting an acquittal.

A before-and-after approach, which would authorize a trial judge to dismiss before or after jeopardy but not during trial, would better protect both the defendant's and the government's interests. It would eliminate the possibility of a second trial and would greatly reduce the opportunity for prosecutorial and judicial manipulation. It would also

96. FED. R. CRIM. P. 29(a) provides:

Motions for directed verdict are abolished and motions for judgment of acquittal shall be used in their place. The court on motion of a defendant or of its own motion shall order the entry of judgment of acquittal of one or more offenses charged in the indictment or information after the evidence on either side is closed if the evidence is insufficient to sustain a conviction of such offense or offenses. If a defendant's motion for judgment of acquittal at the close of the evidence offered by the government is not granted, the defendant may offer evidence without having reserved the right. 
eliminate the necessity for a time-consuming and unpredictable appellate search through the record for an acquittal. At the same time, it would better protect the government's interest in convicting guilty criminals, allow appellate courts to supervise errant trial judges, and proinote the uniform development of the law by allowing the governinent to appeal all dismissals. The Scott Court recommended voluntary adoption of the before-and-after approach as a way of reconciling the government's interest with the defendant's double jeopardy imterests. ${ }^{97}$ The Court should nnake the approach mandatory.

James D. Gordon III*

97. See note 82 supra.

* B.A. 1977, Brigham Young University; J.D. 1980, Boalt Hall School of Law, University of California, Berkeley. 